\title{
Fundamental Effect of Implementation of Corporate Social Responsibility and Value Based Management on the Equity Value of Hotels in Bali
}

\author{
Gede Adi Yuniarta ${ }^{1}$ and I Gusti Ayu Purnamawati ${ }^{2 *}$ \\ ${ }^{1,2}$ Universitas Pendidikan Ganesha, Singaraja Bali, Indonesia
}

\begin{abstract}
Objective - The purpose of this study was to examine the implementation of the fundamental effects of Corporate Social Responsibility and Value Based Management on the Equity Value of hotels in Bali.

Methodology/Technique - The data collecting used purposive sampling method. The effects of moderating variables were tested using Moderated Regression Analysis (MRA).

Findings - The research proves that there is a significant fundamental effect of the implementation of Corporate Social Responsibility and Value Based Management on the Equity Value of hotels in Bali. The fundamental effects prove that although the implementation of Corporate Social Responsibility cause the release of funds that is quite significant but it gives positive effects on companies that has fundamentally led to increased equity value in the eyes of investors.

Novelty - The study proves that the expenditure on Corporate Social Responsibility can positively affect the stock price of a firm.
\end{abstract}

Type of Paper: Empirical

Keywords: Hotel; Value Based Management; Corporate Social Responsibility; Equity Value of The Company. JEL Classification: M14, M41.

\section{Introduction}

A hotel is a type of business entity which combines products and services. The existence of hotels in Bali provides a tremendous effect on the economic growth. In line with such development, there is a necessity for hotels to provide a positive contribution directly to the government and society in their surrounding areas as part of their Corporate Social Responsibility. On the other hand, investors as a decision maker in the implementation of Corporate Social Responsibility programs need an outcome which reflects the effect of the implementation of a Corporate Social Responsibility program towards the improvement of a company's performance (Diatmika, Adi Yuniarta, 2011). In addition to that, information on the outcome which reflects the effect of the implementation of a Corporate Social Responsibility program is also needed in the implementation of SAK ETAP (Standar Akuntansi Keuangan untuk Entitas Tanpa Akuntabilitas Publik/Financial Accounting Standards for Entities without Public Accountability) on cooperatives and SMEs

\footnotetext{
* Paper Info: Received: October 28, 2016

Accepted: April 14, 2017

* Corresponding author:

E-mail: igapurnamawati@gmail.com

Affiliation: Universitas Pendidikan Ganesha, Indonesia
} 
(Adi Yuniarta, 2012). Investors also conduct a review of the performance of a company by looking at its financial ratio as an investment evaluation tool (Sri Rahayu, 2010). Through financial ratios, one can see the success of the company's management in managing the company's assets and capital to maximize the value of the company. If investors wish to see the return on investment generated by the company, the first thing that they will observe is the company's performance demonstrated by its ability to generate profits. The better the performance of a company, the greater its ability to generate profits, and this by itself will generate a positive signal for investors to make investment.

Studies that analyzed the influence of companies' performance on their value are among others conducted by Saepudin (2008), Johnny Jerry (2008), Ardiani (2007), Ulupui (2007). The theory underlying these studies is that the better the financial performance of a company, the higher its value will be. Research conducted by Ardiani (2007) proved that Capital Adequacy Ratio (CAR), Return on Risk Assets (RORA) and Loan to Deposit Ratio (LDR) have a significant effect on stock changes. Ulupui (2007) proved that Return on Assets (ROA) have a significant positive effect on return on stocks for one period ahead. Makaryawati (2002), Carlson and Bathala (1997) in Suranta and Pratana (2004) also found that ROA has a positive effect on company value. Andri and Hanung (2007) also found that investment opportunity set and leverage have an effect on company value. The research outcomes were in line with the argument that the better the financial performance of a company, the greater its value will be. A company's value is also indicated by the price of its shares in the stock market.

Nevertheless, a different finding was obtained by Sasongko and Wulandari (2006) in Sri Rahayu (2010) who examined the effect of Economic Value Added (EVA), ROA, ROE and EPS on stock prices. The research proved that it is only the EPS that affects stock prices. Likewise, the same result was obtained by Wibowo (2005) who examined the effect of EVA, ROA, and ROE on shareholders' return. Partial statistical tests on each independent variable, namely EVA, ROA, and ROE did not show that they have a significant effect on stock returns, and therefore, these variables do not have a partial effect on stock returns. Up to the present time, a company's performance is commonly measured by its financial ratio for one specific period (Utomo, 1999). This financial ratio is highly dependent on the accounting method used in preparing the company's financial statements. This often results in a view that the company's performance is good and improving, yet it may not be the case. In fact, the company's performance may even decline. In line with this idea, Pradhono and Christiawan (2004) also mentioned that measuring financial performance based on accounting profit, such as earnings per share, price earnings ratio and return on equity, is no longer considered adequate to evaluate the effectiveness and efficiency of the company. Therefore, currently many companies use performance indicators that emphasize more on value or it is called Value-Based Management (Hartanti \& Monika, 2008).

The equity value of a company can be a reflection of the company's value. Beaver and Ryan (2000) in Watts (2003) used market to book ratio of equity, which reflects the market value relative to company value. The ratio of market value to book value gives a final assessment and possibly the most thorough assessment on the status of the company in the stock market. This ratio summarizes investors' views about the company's overall performance either in terms of management, earnings, liquidity or the future prospects of the company (Walsh, 2003). Market to book ratio of equity indicates that the market assesses the company's future return on investment from the expected return on equity (Smith \& Watts, 1992; Hartono, 1999). The difference between the market value and the book value of equity indicates companies' investment opportunities (Collins $\&$ Kothari, 1989). Based on this background, the purpose of this study is to determine the fundamental effect of the implementation of Corporate Social Responsibility and Value-Based Management on the equity value of starred hotels in Bali.

\section{Research Method}

First, as a reference for the conduct of this study, a research design that serves as the plan of the research structure was prepared in advance. Research design serves to direct research process and helps generate a valid, objective, efficient and effective research outcome. It is a framework to show the variables used in the study, 
and describes steps for any research activities. Designing a research means determining the type of research, the data to be used and designing an empirical model to test the hypotheses built (Jogiyanto, 2007).

The variables used in the design of this study are: (1) an independent variable, namely Value-Based Management, (2) a moderator variable, namely Corporate Social Responsibility, (3) a dependent variable, namely company equity value, and (4) control variables, namely company size and type of the industry. Based on the background of the study, the research problems were formulated, and the research hypothesis were made. Before conducting a statistical test, it is necessary to determine the research sample, data sources, and data collection methods. The data were processed using a multiple linear regression model with an interaction test (Moderated Regression Analysis).

\section{Result and Discussion}

This study uses starred hotels in Bali as the research object. The research sample was determined using the purposive sampling method that is a method of taking samples based on certain criteria. The criteria used in sampling in this study are: (1) the hotels are starred hotels in Bali, (2) they publish their CSR reports from year 2008 to 2014, and (3) the hotels have complete data on the variables used in the study. A request on data collection was submitted to 50 starred hotels throughout Bali. However, only 43 hotels were willing to be a research object and to provide their financial data. Of the 43 hotels, it turned out that there were 17 hotels having incomplete data on information to be used as research material, and therefore, the total number of hotels having complete data that could be analyzed in this study was 26 starred hotels in Bali.

From the result of the descriptive statistical test, the information obtained is as follows: MBR variable has a value ranging from 0.03 to 36 . The lowest value is owned by the hotel with the PISN code and the highest value is owned by the hotel with the PBSN code. The MBR average value is 7.174 and the standard deviation is 1.002. EVA variable is a proxy of Value Based Management, and has a value ranging from -13.9 to 33.8. The lowest EVA value is owned by the hotel with the BTND code and the highest value is owned by the company with the code of 33.8. The average value of EVA is at 11.352, while the standard deviation is 2.53 . CSRI variable has a range of values from 0.03 to 0.40 . The lowest value is owned by the hotel with the ARUB code, and the highest one is owned by the hotel with the ARND code. The average value of CSRI is 0.27 and the standard deviation is 0.687 . Size variable has a value ranging from 767 to 87.101 . The lowest value is owned by the hotel with the MSSN code and the highest one is owned by the company with the KRSN code. The average value of size is 30.203 and the standard deviation is 1.81443 . Profile variable is a dummy variable with values ranging from 0 to 1 . The average value of profile is 0.13 and the standard deviation is 0.43 .

The coefficient of determination (Adjusted R Square) essentially measures a model's ability in explaining its dependent variables (Ghozali, 2009). The value of the coefficient of determination is between zero and one. Coefficient of determination that is small in number indicates a very limited ability of the independent variables in explaining the variation of dependent variables. A value close to one indicates that the independent variables provide almost all of the information needed to predict the variation of the dependent variables. The result of the test showed that the coefficient of determination of 0.230 indicates that 23 percent of the dependent variable, namely the MBR can be explained by the variable EVA, CSRI, EVA*CSRI, PROFILE and SIZE. The remaining $77 \%$ is explained by other variables that are not incorporated into the model.

From the output, the result of the statistical test of $F$ indicates the calculated value of $F$ that is 4.945 with a significance of 0.000 , smaller than the real level that was set at 0.05 . This result indicates that the regression can be used to predict the MBR or it can be said that EVA, CSRI, EVA*CSRI, PROFILE and SIZE jointly affect the MBR. Statistical test basically shows the influence of an independent variable in explaining the dependent variables. The t-test was used in this study to test the hypothesis. The result of the t-test showed a partial effect of EVA, CSRI, EVA*CSRI, PROFILE and SIZE variables on the MBR. Thus the regression equation becomes:

$\mathrm{MBR}=1.213+0.217 \mathrm{EVA}+0.119 \mathrm{CSRI}+0.39 \mathrm{EVA} * \mathrm{CSRI}+0.21 \mathrm{SIZE}+0.661 \mathrm{PROFILE}$ 
The t-test result showed that the five variables included in the regression model, EVA provides a parameter coefficient of 0.217 with a significance level of 0.005 , which indicates that it provides a significant impact on the MBR. The EVA regression coefficient of 0.217 , means that every addition of $1 \%$ of EVA to the company will increase the company's equity by $0.217 \%$. Meanwhile, CSRI provides a parameter coefficient of 0.119 with a significance level of 0.003 , which means that it gives a significant impact on the MBR. The CSR regression coefficient of 0.119 , means that every addition of $1 \%$ of CSRI to the company will increase the company's equity value by $0.119 \%$. The moderator variable of EVA*CSRI provides a parameter coefficient of 0.139 with a significance level of 0.004 , which means that it gives a significant impact on the MBR. The meaning of the regression coefficient of EVA*CSRI of 0.139 is that each addition of $1 \%$ of EVA to the company will increase the company's equity by $0.139 \%$. SIZE provides a parameter coefficient of 0.210 with a significance level of 0.043 , which means that it poses a significant impact on the MBR. The meaning of the regression coefficient of SIZE of 0.043 is that every addition of 1\% of EVA to the company will increase the company's equity by $0.043 \%$. As for PROFILE, it provides a parameter coefficient of 0.661 with a significance level of 0.095 , which means that it does not provide a significant impact.

The purpose of this study is to determine the fundamental effect of the implementation of Corporate Social Responsibility and Value-Based Management on the equity value of starred hotels in Bali. The end product of this study is: (1) an empirical proof of the theory that can contribute to the field of accounting and investments with regard to the fundamental effect of the implementation of Corporate Social Responsibility and ValueBased Management on the equity value of starred hotels in Bali.

In this study the fundamental effect of the implementation of Corporate Social Responsibility and ValueBased Management on the equity value of starred hotels in Bali is proven by analyzing the effect of several variables that include Corporate Social Responsibility (measured by CSRI), Value-Based Management (measured by EVA), the moderator variable, namely Corporate Social Responsibility (CSRI*EVA), and the control variables, namely company size and company profile. The results proved that EVA provides a parameter coefficient of 0.217 with a significance level of 0.005 , which means that it provides a significant impact on the MBR. The meaning of the EVA regression coefficient of 0.217 is that every addition of $1 \%$ of EVA to the company will increase the company's equity by $0.217 \%$. Meanwhile, CSRI provides a parameter coefficient of 0.119 with a significance level of 0.003 , which means that it gives a significant impact on the MBR. The CSR regression coefficient of 0.119 , means that every addition of $1 \%$ of CSRI to the company will increase the company's equity value by $0.119 \%$. The moderator variable of EVA*CSRI provides a parameter coefficient of 0.139 with a significance level of 0.004 , which means it has a significant impact on the MBR. The meaning of the EVA*CSRI regression coefficient of 0.139 is that every addition of $1 \%$ of EVA to the company will increase the company's equity by $0.139 \%$. Meanwhile, SIZE provides a parameter coefficient of 0.210 with a significance level of 0.043 , which means that it poses a significant impact on the MBR. The meaning of the SIZE regression coefficient of 0.043 is that every addition of $1 \%$ of EVA to the company will increase the company's equity by $0.043 \%$. As for PROFILE, it provides a parameter coefficient of 0.661 with a significance level of 0.095 , which means that it does not have a significant influence.

The results of this analysis can be discussed as follows: an increase in the value of a company is usually marked by the rise of its share prices in the stock market. This study used a proxy of market to book ratio of equity for company equity assessment. The ratio of market value, to book value provides a final assessment and possibly the most thorough assessment on the status of the company's stock market. This ratio summarizes the investors' views about the company as a whole in terms of its management, earnings, liquidity and future prospects of the company (Walsh, 2003).

Investors conduct a review of a company's performance by looking at its financial ratio as an investment evaluation tool (Sri Rahayu, 2010). Through financial ratios, one can see the success of the management of a company in managing its assets and capital to maximize its value. If investors wish to see how big the return on investment that a company can generate, the parameter which the investors will see first is the ratios associated with the company's ability in generating profits. The bigger the ratios, the greater the company's 
ability to generate profits, which in turn can generate a positive signal for investors in making investment in the company.

The company's performance can be assessed by the company's ability in generating profits. Apart from being an indicator of a company's ability in fulfilling its obligation to its creditors, company profits also serve as an element in generating the company's value that will demonstrates the company's prospects in the future.

This study shows that Value Based Management with EVA as the proxy is proven to be able to affect companie's equity value. This is shown by the result of EVA statistics which provides a parameter coefficient of 0.217 with a significance level of 0.005 , which means that it has a significant impact on the MBR. The meaning of the EVA regression coefficient of 0.217 is that every addition of $1 \%$ of EVA to the company will increase the company's equity by $0.217 \%$. These results are in line with the argument that the better the financial performance of a company, the higher the value of the company will be. These results are also consistent with the results of the studies which state that EVA has a good correlation with stock returns (Lehn, Makhija 1996; Esa Makelainen 1997; Dodd, Chen 1996).

This result of this research are also consistent with the studies that had been conducted by Ulupui (2007), Makaryawati (2002), Carlson and Bathala (1997), Suranta and Pratana (2004), Maryatini (2006), Andri and Hanung (2007), Hanafi and Halim (1996), Ross (2002), Kennedy JSP (2003), and Saefudin (2008). However, this study is not consistent with the research conducted Sasongko and Wulandari (2006) and Wibowo (2005).

The results of this study indicate that the public reporting of CSR is proven to affect the companie's equity value. This is shown by the CSRI statistical result that provides a parameter coefficient of 0.119 with a significance level of 0.003 , which means that it has a significant impact on the MBR. The meaning of the regression coefficient of CSR of 0.119 is that every addition of $1 \%$ of CSRI to the company will increase the company's equity value by $0.119 \%$. The results of this study are consistent with the results of the studies that had been carried out by: McGuire et al (1998), Balabanis, Phillips, and Lyall (1998), Heal and Garret (2004), Finch (2005), Siegel and Paul (2006), Nurlela and Islahuddin (2008), which concluded that CSR has a significant effect on company value. Theoretically speaking, the disclosure of CSR should be of investors' consideration before investing, because CSR report contains information on what social activities the company has conducted. Such information is expected to be considered by investors in making investment.

Disclosure of Corporate Social Responsibility activities moderates the relationship between Value-Based Management and company equity value. The moderating variable of EVA*CSRI provides a parameter coefficient of 0.139 with a significance level of 0.004 , which means that it has a significant impact on the MBR. The meaning of the EVA*CSRI regression coefficient of 0.139 is that each addition of $1 \%$ of EVA to the company will increase the company's equity by $0.139 \%$. The results of this study are consistent with the research that had been carried out by Yuniasih and Wirakusuma (2009) and other studies that have an outcome stating that CSR has a positive effect on company value such as research conducted by Heal and Garret (2004), Siegel and Paul (2006), Nurlela and Islahuddin (2008). In theory, the disclosure of CSR should be a consideration of the investor before investing. Good financial performance coupled with a disclosure of CSR is expected to be considered by investors in making investment. However, the results of this study indicate that investors do not respond to the disclosure of CSR that has been conducted by the company.

This study used control variables, namely the company's Size and Profile. Large companies are said to be more stable and more capable of generating profits than smaller companies, which in turn enables them to generate more profits compared to smaller companies. This makes their value become higher than that of smaller companies. Likewise, companies with a high profile are said to have a better performance than companies with a low profile, and having a higher profile increases a company's value.

The results of this study indicate that SIZE provides a parameter coefficient of 0.210 with a significance level of 0.043, which means that it has a significant impact on the MBR. The meaning of the SIZE regression coefficient of 0.043 is that each addition of $1 \%$ of EVA to the company will increase the company's equity by $0.043 \%$. As for the PROFILE, it gives a parameter coefficient of 0.661 with a significance level of 0.095 which means it does not give a significant effect. This is indicated by the fact that investors in making their decisions 
on investment are more likely to pay attention to companies' Value Based Management. They may have a view that the main purpose of investing is to get a maximum possible return. Upon looking at a good EVA they may not need to see the Size and Profile of the company.

Based on the discussion above, it can be proven that there is a fundamental effect of the implementation of Corporate Social Responsibility and Value-Based Management on the equity value of starred hotels in Bali. This is evidenced by the significant effect of Corporate Social Responsibility and Value-Based Management on the equity value of the starred hotels in Bali in this research. This fundamental effect proves that although the implementation of Corporate Social Responsibility requires a considerable amount of fund spent by the starred hotels, the end result is a positive effect on the hotels that fundamentally causes a rise in the stock price/selling price of the hotels in the eyes of investors.

\section{Conclusion}

The fundamental effect of the implementation of Corporate Social Responsibility and Value-Based Management on the value of equity of starred hotels in Bali is proven by result of analysis of the effect of several variables that include Corporate Social Responsibility (measured by CSRI), Value-Based Management (measured by EVA), a moderating variable that is Corporate Social Responsibility (CSRI*EVA), and the control variables, namely company size and company profile. The research proves that there is a fundamental effect of the implementation of Corporate Social Responsibility and Value-Based Management on the value of equity of starred hotels in Bali. This is evidenced by the significant effect of Corporate Social Responsibility and Value-Based Management on the value of the equity of the starred hotels in Bali under this research. This fundamental effect proves that although the implementation of Corporate Social Responsibility requires the starred hotels to spend a considerable amount of funds, the result that can be obtained is positive and it can contribute to a rise in the stock price/selling price of the starred hotels in the eyes of investors.

\section{References}

Yuniarta, A., \& Bagia, W. (2012). Pelatihan Implementasi Standar Akuntansi Keuangan (SAK) ETAP pada Koperasi dan UKM di Kabupaten Buleleng.

Rachmawati, A. \& Triatmoko, H. (2007). Analisis Faktor-Faktor yang Mempengaruhi Kualitas Laba dan Nilai Perusahaan [Analysis of Factors Affecting Profitability and Corporate Values]. Simposium Nasional Akuntansi X. Makasar, $26-28$ Juli.

Anita Ardiani. (2007). Analisis Pengaruh Kinerja Keuangan Terhadap Perubahan Harga Saham Pada perusahaan Perbankan di BEJ [Analysis of the Effect of Financial Performance on Stock Price Changes In Banking Companies at BEJ]. Fakultas Ekonomi Universitas Negeri Malang, Indonesia

Brigham, E. F., \& Houston, J. F. (2001). Manajemen Keuangan [Financial Management]. (8 ${ }^{\text {th }}$ Ed.). Jakarta: Erlangga.

Collins, D. W., \& Kothari, S. P. (1989). An analysis of intertemporal and cross-sectional determinants of earnings response coefficients. Journal of accounting and economics, 11(2-3), 143-181.

Diatmika, I. P. G. (2012). Pengembangan kamus" chart of accounts" untuk mata kuliah akuntansi perhotelan. Jurnal Ilmu Sosial dan Humaniora, 1(1).

Hartanti, D. \& Monika, E.R. (2008). Analisis Hubungan Value Based Management dengan Corporate Social Responsibility dalam Iklim Bisnis Di Indonesia [Analysis of Value Based Management Relations with Corporate Social Responsibility in Business Climate In Indonesia]. Simposium Nasional Akuntansi XI. Pontianak

Johnny Jerry. (2008). Analisis Ratio Fundamental, Kinerja Keuangan dan Resiko Pasar Pada Industri Perbankan di BEI terhadap Perubahan IHSG [Fundamental Ratio Analysis, Financial Performance and Market Risk in the Banking Industry at IDX on JCI Change]. Fakultas Ekonomi Gunadarma

Jogiyanto. (2007). Metodelogi Penelitian Bisnis: Salah Kaprah dan Pengalaman- Pengalaman [Business Research Methodology: Wrong Experience and Experience-Experience]. FE UGM: BPFE Yogyakarta

Nurlela \& Islahudin. (2008). Pengaruh Corporate Social Responsibility terhadap Nilai Perusahaan dengan Prosentase Kepemilikan Manajemen sebagai Variabel Moderating. Simposium Nasional Akuntansi XI

Paul A. S. (1999). Value Based Management. Focused Mangement Information. 
Pradhono, P., \& Christiawan, Y. J. (2005). Pengaruh Economic Value Added Residual Income Earnings Dan Arus Kas Operasi Terhadap Return Yang Diterima Oleh Pemegang Saham [Effect of Economic Value Added Residual Income Earnings and Operating Cash Flows on Return Received by Shareholders]. Jurnal Akuntansi dan Keuangan, 6(2), 140-154

Saepudin. (2008). Pengaruh Antara Ratio Profitabilitas dan Investment Opportunity Set Terhadap Harga Saham Perusahaan yang Terdaftar di BEI tahun 2005 sampai 2007 [Pengaruh Antara Ratio Profitabilitas dan Investment Opportunity Set Terhadap Harga Saham Perusahaan yang Terdaftar di BEI tahun 2005 sampai 2007]. Simposium Nasional Akuntansi XI

Smith, C. W., \& Watts, R. L. (1992). The investment opportunity set and corporate financing, dividend, and compensation policies. Journal of financial Economics, 32(3), 263-292.

Sri Rahayu. (2010). Pengaruh Kinerja Keuangan Terhadap Nilai Perusahaan Dengan Pengungkapan CSR dan GCG sebagai Variabel Pemoderasi [Pengaruh Kinerja Keuangan Terhadap Nilai Perusahaan Dengan Pengungkapan CSR dan GCG sebagai Variabel Pemoderasi]. Skripsi, Sarjana Jurusan Akuntansi Fakultas Ekonomi Universitas Diponegoro Semarang

Sugiyono. (2009). Metode Penelitian Bisnis [Business Research Methods]. Bandung: CV. Alfabeta

Suranta, E., \& Merdistuti, P. P. (2004). Income smoothing, Tobin's Q, agency problems and company performance. Simposium Nasional Akuntansi VII.

Ulupui, I. G. (2007). Analisis pengaruh rasio likuiditas, leverage, aktivitas, dan profitabilitas terhadap return saham (studi pada perusahaan makanan dan minuman dengan kategori industri barang konsumsi di BEJ) [Analysis of the influence of liquidity ratio, leverage, activity, and profitability on stock return (study on food and beverage companies with consumer goods industry category at BEJ)]. Jurnal Ilmiah Akuntansi dan Bisnis, 2(1).

Utomo, M. M. (2000). Praktek Pengungkapan Sosial pada Laporan Tahunan Perusahaan di Indonesia (Studi Perbandingan antara Perusahaan-Perusahaan High-Profile dan Low Profile)[ Social Disclosure Practices on Company Annual Report in Indonesia (Comparison Study between High-Profile Companies and Low Profile)]. Simposium Nasional Akuntansi, 3, Jakarta, Indonesia.

Walsh, C. (2003). Key Management Ratios: Rasio-rasio Manajemen Penting Penggerak dan Pengendali Bisnis. [Key Management Ratios: Drivers and Operators Important Ratios Management Ratios]. ( ${ }^{\text {rd }}$ Ed.) Jakarta: Penerbit Erlangga.

Watts, R.L. (2003). A Proposal for Research on Conservatism. Working paper, Massachusetts Institute of Technology

Wibowo, L.B. (2005). Pengaruh Economi Value Added dan Profitabilitas Perusahaan Terhadap Return Pemegang Saham [The Influence of Value Added Economics and Profitability of the Company Against Returns of Shareholders]. Fakultas Ekonomi Universitas Islam Indonesia Yogyakarta.

Wolk, H. I., Tearney, M. G., \& Dodd, J. L. (2001). Accounting Theory-A Conceptual and Institutional Approach, South. Ohio, OH: Thomson South-Western. 